\title{
Analyzing the Relationship between Ethical Leadership and Organizational Justice and Organizational Identification in Schools*
}

\section{Research Article}

\section{Hatice MIHCI ${ }^{1}$, Tevfik UZUN ${ }^{2}$}

${ }^{1}$ MEB, 19 Eylül Primary School, Giresun, Turkey, ORCID: 0000- 0001-7325-769X

${ }^{2}$ Giresun University, Faculty of Education, Department of Educational Management, Giresun, Turkey, ORCID: 0000-0002-6505-2421

To cite this article: Mihci, H., \& Uzun, T. (2020). Analyzing the Relationship between Ethical Leadership and Organizational Justice and Organizational Identification in Schools, International Online Journal of Educational Sciences, 12(3), 29-39.

\begin{tabular}{l} 
ARTICLE INF \\
\hline Article History: \\
Received: 12.02 .2020 \\
Available online: \\
13.07.2020
\end{tabular}

13.07.2020

\begin{abstract}
The relationships between ethical leadership, organizational justice and identification in schools are analyzed in this research. The sample of this research includes in 315 teachers working in primary schools affiliated to the Ministry of National Education in Giresun central district in 2017. The research is in correlational survey model. The consequences of the research demonstrate that there is a positive relationship between the ethical leadership of school principals and teachers' perceptions of organizational justice and their organizational identification. Ethical leadership behaviors of school principals predict the organizational justice and organizational identification perception of the teachers and a teachers' perception of organizational justice significantly predicts their organizational identification. The perception of organizational justice plays an intermediary role in the relationship between the principal's ethical leadership behavior and the organizational identification of teachers in accordance with the consequences of the research. It is considered that the consequences of the research will contribute to the evaluation of leadership, equality and identification theories from the holistic perspective in the field of educational administration.
\end{abstract}

C 2020 IOJES. All rights reserved

Keywords:

Ethical leadership, organizational justice, identification

\section{Introduction}

The administrative attitudes have been considered insufficient by itself, the leadership features that administrators should possess started to be focused in today's schools and this has increased the significance of the leadership types demonstrated by the administrators and the perceptions, reactions and behaviors that

\footnotetext{
* This article is mainly derived from the responsible author's master thesis titled "Investigation on the relationship between ethical leadership and organized justice and organizational identification in the schools (Sample of Giresun)".

${ }^{1}$ Corresponding author's address: 19 Eylül Primary School, Giresun, Turkey,

Telephone: 5334755462

e-mail: haticemihci@gmail.com

DOI: https://doi.org/10.15345/iojes.2020.03.003
} 
these leadership behaviors enhance on teachers. The leaders are the persons whose way are followed and considered as a model by the workers. This situation makes essential the leaders to adopt ethical principles as a principle both in all their personal and professional attitudes and behaviors. Therefore, many studies have been carried out regarding leadership and many types of leadership have been put forward. Ethical leadership is a type of leadership that has been dwelled upon and emphasized in the studies performed in the recent times. Ethical leadership is a leadership approach consisting of possessing certain ethical principles and setting model by showing these values. (Kolçak, 2013). Ethical leaders represent the goals, vision and values of the organization and its founders within the framework of the understanding of ethical bounds and provide the relation between the goals of the organization and employees and external stakeholders (Kumar, 2015). Ethical leaders are the persons who are mostly interested in kindness, modest, work for justice, take responsibility and respect every individual. These leaders determine high ethical standards and act in accordance with these standards. They are perceived as honest, trustworthy and courageous individuals and affect the ethical values of the organization through their behaviors (Mihelic, Lipicnik and Tekavcic (2010). Ethical leadership has six components: the character, actions, goals, honesty, power and values of the leader (Gedikoğlu, 2015). The levels of leaders' showing leadership contribute to the institutionalization of organizations in terms of ethical standards. When a leader does not believe in something, he/she may not be able to inspire his/her followers through his/her behaviours. Therefore, exemplary behaviours of a leader for individuals in the organization will contribute to the increase of ethical behavior levels of the organization (Turan, 2014). The research conducted in the field of education outs forward that perceived organizational justice is among the significant consequences of ethical leadership (McCabe and McCarthy, 2005; Uğurlu and Üstüner, 2011; Ayık, Yücel and Savaş, 2014).

The perception of work and processes as fair by workers takes at the first place of the conditions required for teachers, who are among the most important stakeholders of the schools, to demonstrate both individual satisfaction and happiness, and the duties and responsibilities at the level expected from them in the organization. Organizational justice is an issue related to the ways that employees use their workplaces to determine whether they are treated fairly or not and how employees' perceptions of justice affect other issues with regard to their job (Moorman, 1991) and based on Adams' theory of equality. According to this theory, individuals compare the concrete acquisitions they gain in return for the work they do with the labor they provide and the acquisitions of others, and they perceive this situation as it is injustice if they think these acquisitions they gain are insufficient (Cropanzano, Byrne, Bobocel and Rupp, 2001). As a result of the perception of injustice, individuals develop various behaviors. The behaviors they develop may be towards individuals or mostly towards the organization (Altıntaş, 2006). The perception of injustice may lead to the occurence of tendencies in individuals such as retaliating, slowdown, quitting work or even employee theft (Tarkan and Tepeci, 2006). Organizational justice is a phenomenon consisting of the paying regard to and dissemination of justice and moral rules in practices within the organization (İşcan and Naktiyok, 2004). When the literature is reviewed, organizational justice are generally classified in three dimensions. These are distributive, procedural and interactional justices. The fair distribution of acquisitions gained in the organization is the subject of distributive justice, while the decisions taken regarding the distribution of acquisitions is the subject of procedural justice and the interpersonal relations in the organization is the subject of interactional justice (Chan-Charash and Spector, 2001; İçerli, 2010, Özdevecioğlu, 2004). The great majority of the daily lives of the workers have been spent at workplaces. Therefore, most of the events dominating individuals' perceptions of justice takes place at workplaces. Individuals compare themselves with other workers frequently in their work life, and speculate on whether decisions and awards are equal. These comments are the consequences of perceived organizational justice and influence employees' attitudes and behaviors within the organization (Irak, 2004). 
The perceptions, attitudes and behaviors of the workers with regard to the organization and their work are of significant role in the success of the organization's purposes. This situation sets foth the significance of the psychological relationship established between the workers and the organization. Organizations want their employees to enhance their emotions such as love, respect, loyalty and belonging and to identify with themselves. Organizational identification, on the other hand,is expressed as belonging to an organization that the individual defines himself/herself in terms of the organization in which he/she is a member or to feel a sense of belonging to this organization (Mael and Ashforth, 1992). Organizational identification enabling the workers to adopt the organizations they are subject to and to be happy to be a part of this organization, influences positively their performance (İşcan, 2006). Organizational identification is based upon the social identity theory (Mael and Ashforth, 1992). Although there are many definitions in the literature related to the organizational identification, the common point of these definitions is that individual associates himself/herself with the organization to which he/she is subject, cognitively, emotionally or in both ways (Taşlihan, Hırlak and Çiftçi, 2016). To what extent an individual is attached to the organization to which he/she is subject, it means that he/she has been identified with that organization at the same level. If an individual cares more about that organization than any other organization he/she is subject to, it means he/she has been identified with that organization at an advanced level (İşcan and Karabey, 2007). The level of organizational identification may be evaluated by the common point degree in which he/she reaches in the concepts he/she uses to define himself/herself and the organization. An individual experiencing organizational identification accepts the organization in which he/she is included as his/her own organization and is glad to be a part of this organization. Therefore he/she does not want to leave this organization and when he/she leaves, he/she thinks that he/she has lost a part of his/her own (Öktem, Kızıltan and Öztoprak, 2016).

The researches carried out in the field of education demonstrates that the ethical leadership of school principals positively influences the teachers' perceptions of social and organizational justice (McCabe and McCarthy, 2005; Uğurlu and Üstüner, 2011; Ayık, Yücel and Savaş, 2014, Kuğun, Aktaş and Köripek, 2013, Özdemir, 2009). The studies performed in various fields demonstrate that the ethical leadership showed by their administrators increases the organizational identification of the workers (Walumbwa, Mayer, Wang, Wang and Worgman, 2011; Sökmen, Ekmekçioğlu and Çelik; Alkan and Arıkboğa, 2017; Başar, Sığrı and Basım, 2017; Türk and Akbaba, 2018). In addition to this, some studies demonstrate that the organizational justice perceptions of teachers predict the organizational identification of teachers (Uzun, 2018). In addition to these, the research conducted in different fields show that as the perception of organizational justice increases, the organizational identification of the workers increases as well (Cheung and Law, 2008; Çetinkaya and Çimenci; 2014; Olkkonen and Lipponen, 2006;). These three variables have been handled, yet the relationships between the variables have not been tested within a model in Öktem's (2013) study in the field of tourism.

It is observed that there are a limited number of studies dealing with the relationships between the concepts of ethical leadership, organizational identification and organizational justice when the body of literature is analyzed. Three variables were tested in a model at the same time with the current research that was conducted. The research will make significant contribution to educational managers and researchers in the evaluation of leadership equality and identification theories from a holistic perspective. The findings acquired from this study may provide a different perspective to practitioners and researchers in terms of understanding the organizational behavior of teachers in school.

Answers to the following questions have been searched in this study.

1. Is there an important relationship between the ethical leadership of school principals and the organizational justice and organizational identification perception of the teachers?

2. Does the ethical leadership of school principals influence the perceptions organizational justice and organizational identification of teachers? 
3. Does the perception of organizational justice play an intermediary role in the relationship between the ethical leadership of school principals and the organizational identification of teachers?

\section{Method}

\section{Research Model}

The correlational survey model was used in this research revealing the relationships between the ethical leadership of school administrators, organizational justice perception and organizational identification of teachers. The research model has been showed in figure 1.

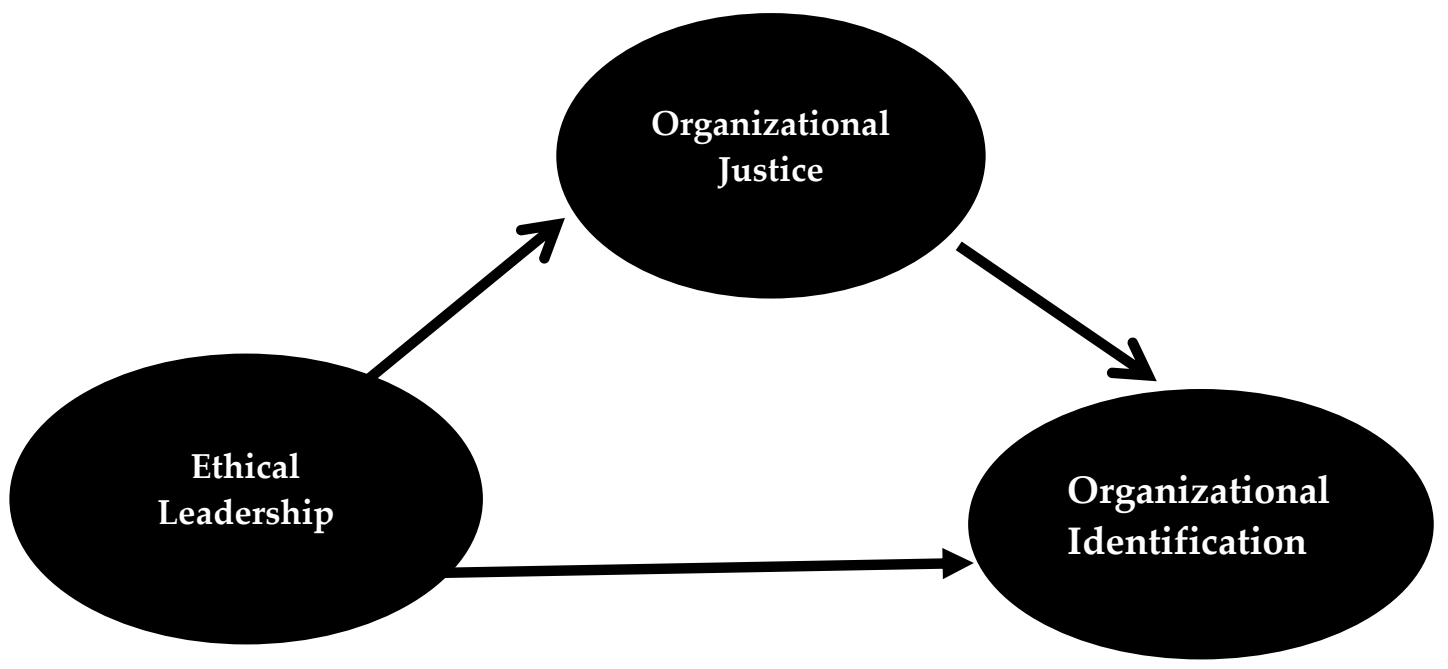

Figure 1. Research Model

\section{The Sample of the Research}

The population of the research consists of 315 teachers working in primary schools affiliated to the Ministry of National Education in Giresun central district in 2017. Since the entire population was reached, the sample of the study was determined as the population sample. The accessible population is a concrete population with realistic selection that the researcher are able to reach (Büyüköztürk et al., 2014). The scale forms were distributed to 295 teachers by the researcher. 242 of the distributed forms were returned and 53 forms were not made a come-back. 12 of the 242 returned forms were not evaluated because of incomplete filling of the forms. The research analysis was conducted with 230 forms.

\section{Data Collection Tools}

Ethical leadership scale: The scale that was adapted to Turkish by Tuna, Bircan and Yeşiltaş (2012) was developed by Brown, Treviño and Harrison (2005). The original of it is one-dimensional and has 10 items. Fit indices have been calculated as $\chi 2=84.60 ; \chi 2 / \mathrm{df}=2.42, \mathrm{p}<.01 ; \mathrm{NFI}=.90, \mathrm{IFI}=.94, \mathrm{AGFI}=.90, \mathrm{GFI}=.93, \mathrm{CFI}=$ $.94, \mathrm{RMR}=.23$ according to the consequence of the confirmatory factor analysis on the scale for this research. The one-dimensional structure of the scale was verified. Alpha value is $\alpha=.86$ in this study.

Organizational justice scale: The scale adapted to Turkish by Taşdan and Y1lmaz (2008) was developed by Toy and Harter (2004). The original of it is one-dimensional and has 10 items. Fit indices have been calculated as $\chi 2=131.88 ; \chi 2 / \mathrm{df}=3.77, \mathrm{p}<.01 ; \mathrm{NFI}=.91, \mathrm{IFI}=.93, \mathrm{GFI}=.89, \mathrm{CFI}=.93, \mathrm{RMR}=.19$ according to the consequence of the confirmatory factor analysis on the scale for this research. The single factoral structure of it was verified. Alpha value is $\alpha=.93$ in this study.

Organizational identification scale: The scale was developed by Mael and Ashforth (1992). The original of it is one-dimensional and has 6 items. The scale was adapted to Turkish by Uzun (2018). Fit indices have been calculated as $\chi 2=37.061 ; \chi 2 / \mathrm{df}=4.12, \mathrm{p}<.01 ; \mathrm{IFI}=.90, \mathrm{AGFI}=.87, \mathrm{GFI}=.94, \mathrm{CFI}=.90, \mathrm{RMR}=.0519$ according to 
the consequence of the confirmatory factor analysis on the scale for this research. Thus, the single factoral structure of it was verified. Alpha value is $\alpha=.76$ in this study.

\section{Analysis of Data}

Descriptive analysis, correlation analysis and structural equation model were used in the analysis of the data. Normality and linearity assessment were carried out on the data obtained from 230 forms before the analysis for the purpose of analyzing the compatibility between the data. Coefficient of skewness and kurtosis was used within the scope of normality assessment. The "Dissemination Diagram Matrix" was used for linearity. Since 8 data have been seen as extreme values, they are removed from the data analysis by making extreme values analysis.

\section{Findings}

The average, standard deviation and the relationships between variables are given in the Table 1.

Table 1. Average, standard deviation and correlations of variables

\begin{tabular}{|c|c|c|c|c|c|}
\hline Variables & $\bar{x}$ & Ss & 1 & 2 & 3 \\
\hline 1. Ethical Leadership & 4.27 & 0.47 & - & & \\
\hline 2.Organizational Justice & 4.44 & 0.49 & $.77^{* *}$ & - & \\
\hline 3.Organizational Identification & 4.14 & 0.62 & $.40^{* *}$ & $.44^{* *}$ & - \\
\hline
\end{tabular}

The ethical leadership of school principals, the organizational justice perception and identification of teachers with regard to the schools are at a high level according to the findings. There are positive relationships between the ethical leadership of school principals and the organizational justice perception $(\mathrm{r}=.77, \mathrm{p}<0.01)$ and organizational identification $(\mathrm{r}=.40, \mathrm{p}<0.01)$ of teachers. There is also a positive relationship between teachers' organizational justice perception and organizational identification $(r=.44, p<0.01)$ that they sense for their schools.

Three path analyzes were carried out in order to set forth the effect between the variables. The consequences regarding three path analyzes carried out were specified in Table 2.

Table 2. The consequences of path analysis

\begin{tabular}{|c|c|c|c|c|}
\hline Path & $\beta$ & St. $\mathbf{M}$ & $\mathbf{p}$ & Fit Indices \\
\hline 1.Ethical Leadersip $\Rightarrow$-Identification & .50 & .15 & $0.00^{*}$ & $\begin{array}{c}\chi 2 / \mathrm{df}=2.16, \mathrm{IFI}=0.90, \mathrm{AGFI}=0.86 \\
\mathrm{RMSEA}=0.07\end{array}$ \\
\hline 2.Ethical Leadership & .87 & .09 & $0.00^{*}$ & $\begin{array}{c}\chi 2 / \mathrm{df}=2.27 \mathrm{IFI}=0.91, \mathrm{CFI}=0.91 \\
\mathrm{RMSEA}=0.08\end{array}$ \\
\hline 3.O. Justice $\Rightarrow$.Identification & .73 & .12 & $0.00^{*}$ & $\begin{array}{c}\chi 2 / \mathrm{df}=2.77, \mathrm{IFI}=0.90, \mathrm{CFI}=0.90, \mathrm{GFI}= \\
0.86\end{array}$ \\
\hline
\end{tabular}

Ethical leadership influences positively the organizational justice $(\beta=0.87 ; \mathrm{p}<0.05)$ and organizational identification $(\beta=0.50 ; \mathrm{p}<0.05)$ according to the Table 2 . In addition, organizational justice influences positively organizational identification $(\beta=0.73 ; \mathrm{p}<0.05)$.

The structural equation model has been established for the purpose of putting forward the mediation effect of the organizational justice perception of teaches in the relationship between the ethical leadership of school principals and the organizational identification of teachers. Table 3 shows the results of the analysis with regard to the mediation effect. 
Table 3. Analysis results with regard to mediation effect

\begin{tabular}{|c|c|c|c|c|}
\hline Path & $\beta$ & St. $M$. & $\mathrm{p}$ & Fit indices \\
\hline 1.Ethical Leadersip $\quad$ QIdentification & .05 & .29 & 0.81 & \multirow{3}{*}{$\begin{array}{c}\chi 2 / \mathrm{df}=2.08, \mathrm{p}<0.01, \mathrm{IFI}=0.90, \mathrm{CFI}=0.90, \\
\mathrm{RMSEA}=0.07\end{array}$} \\
\hline 2.Ethical Leadership $\curvearrowright$ Justice & .87 & .10 & $0.00^{*}$ & \\
\hline 3.O. Justice $\$$.Identification & .52 & .28 & $0.01^{*}$ & \\
\hline
\end{tabular}

The effect of ethical leadership on organizational identification has been eliminated by including organizational justice in the relationship between ethical leadership and organizational identification, but the impact of organizational justice on organizational identification proceeds according to the Table 3 . The organizational justice plays a full intermediary role in the relationship between ethical leadership and organizational identification in accordance with the finding.

\section{Conclusion and Suggestions}

Significant results were accomplished in the evaluation of leadership, equality and identification theories in the field of educational management from a holistic perspective. As school principals demonstrate ethical principles and values, determine high ethical standards and act in accordance with them, become a role model in terms of ethical values, behave honestly and objectively towards teachers, teachers feel more that they belong to the school, adapt themselves into it and are glad to be working at the school. In this relation, the thoughts of teachers' on whether the acquisitions in the school are distributed fairly, whether the decisions taken regarding the distribution of these acquisitions are appropriate and whether there is an equality in the interpersonal relations are effective.

As the ethical leadership of school principals increases, organizational identification of teachers increases as well according to the research results. In other words, as school principals demonstrate ethical principles and values, behave honestly and reliably towards teachers, put inner values into practice, teachers also feel that they belong to the school, adapt themselves into it and are glad to be working at school. This result bears a resemblance to the research findings of Yeşiltaş (2012) who stated that ethical leadership behaviors are decisive in the formation of organizational identification in his study in hotel enterprises, Alkan and Arıkboğa (2017) who stated that the ethical leadership of the administrators is the identification of the workers in their study on bank employees and Kılınç (2017) who stated that ethical leadership and organizational identification are related in their research on municipal employees. Ethical leadership has a positive effect on organizational identification according to the results of the research. In other words, as school principals determine high ethical standards and act accordingly, teachers associate themselves with the school cognitively and affectively and are glad to be a part of it. This finding has a resemblance to the research findings of Deconninck (2011), Walumbwa et al. (2011), Ugurlu and Üstüner (2011) and Ayan (2015).

As the ethical leadership of school principals increases, the justice perceptions of teachers increase against executive practices in the organizational school according to the research results. In other words, as school principals become role model in terms of ethical values, behave honestly and fairly towards teachers and do not discriminate and offer equal opportunities, teachers perceive more equality and more justice at school. This result corresponds with the research findings of Acar, Kaya, and Şahin (2012) finding that school administrators have an impact on the level of ethical leadership and the organizational justice perception of teachers, Aylk and Yücel (2014) stating that the level of being an ethical leader is the predictor of the organizational justice perceptions of teachers, Aykanat and Yıldırım (2012) determining the relationship between ethical leadership and organizational justice in their study carried over with Ardahan University administrative personnel Akatay, Yücekaya and Kısat (2016) finding out that ethical leadership behaviors affect the organizational justice perception of the works in their study with police officers and Sonğur, Özer and Şahin (2017) expressing that ethical leadership has an impact on organizational justice in their research 
with public hospital health workers and nurses. Ethical leadership has a positive effect on organizational justice according to the results of the research. In other words, as school principals show normatively appropriate behaviors through personal actions and interpersonal relations, the perceptions of justice of teachers related to the applications at school also increase. This finding has a resemblance to the findings of Ahmad (2018), Tziner, Felea and Vasiliu (2015), Walumbwa, Hartnell and Misati, (2017); Acar, Kaya and Şahin (2012), Ayık, Yücel and Savaş (2014).

As the organizational justice perception of teachers with regard to the executive practices in the school increases, the identification of the teachers towards the school also increases in accordance with the results of the research. In other words, as school principals distribute the acquisitions at school fairly, impartially include teachers in the decisions taken, treat equally towards everyone, the sense of belonging of the teachers related to the school and their loyalties increase. This result supports the research findings of Nergiz (2015), Uzun (2018), Solmaz (2010), Taşliyan, Hırlak, Çiftçi and Yılmaz (2017). setting forth the relationship between the organizational justice perception of teaches and their organizational identification, This result corresponds to the research findings of Turunç (2011) finding the relationship between the organizational justice perception of public and private sector employees and their organizational identification, Cüce, Güney and Tayfur (2013) who present that the organizational justice perceptions of the employees have an impact on their organizational identification in the study they carried out in a public institution, Olkkonen and Lipponen (2006) stating that there is a positive relationship between the organizational justice perception of the employees and their organizational identification and Cheung and Law (2008). Organizational justice has a positive effect on organizational identification according to the research result. In other words, if teachers perceive that acquisitions in the school are distributed fairly, the decisions taken regarding the distribution of these acquisitions are appropriate and there is fairness in the interpersonal relations, they feel more that they belong to the school. This result has a resemblance to the research findings of Olkonen and Lipponen (2006), Cheung and Law (2008), Turunç (2011), Cüce, Güney and Tayfur (2013) and Uzun (2018)

Organizational justice plays a full intermediary role in the relationship between ethical leadership and organizational identification according to the results of the research. In other words, as school principals act in accordance with ethical principles and values, become role model in terms of ethical values, teachers feel more that they belong to school, adapt themselves into it and are also glad to be a part of it. In this relationship, teachers' thoughts on whether the acquisitions in the school are distributed fairly, whether the decisions taken regarding the distribution of the acquisitions are appropriate, and whether there is an equality in the interpersonal relations are effective. This finding has a resemblance to the research findings of Pillai, Teri and Ethlyn (1999) expressing that leadership behaviors have a mediating effect on the perception of justice on organizational commitment, Dalgin and Taslak (2016) deducing that organizational justice plays an intermediary role in the relationship between leadership styles and organizational citizenship behavior and Alpkan, Dilek and Bozlağan (2005).

Ethical leadership behavior should be demonstrated at a high level by school principals. Transparent, open and participatory practices can be enhanced in school management by school principals as an ethical leader. Comparative research can be conducted by studying at some or all of these levels. The research sample only covers the central district of Giresun province. A larger-scale study can be carried out that the general map of Giresun province can be drawn by participating in other districts. A comparative research consisting the whole country can be performed at the level of the region or of all provinces throughout Turkey. The mediating effect of organizational behaviors such as organizational commitment and trust can be tested in the relationship between ethical leadership and organizational identification. 


\section{REFERENCES}

Acar, G., Kaya, M., \& Şahin, M.Y. (2012). Okul yöneticilerinin sergilediği etik liderlik davranışının beden eğitimi öğretmenlerinin örgütsel adalet düzeyine etkisi. Türk Spor ve Egzersiz Dergisi, 14 (3), 51-58.

Ahmad, S. (2018). Can ethical leadership inhibit workplace bullying across East and West: Exploring crosscultural interactional justice as a mediating mechanism. European Management Journal, 36(2), 223-234.

Akatay, A., Yücekaya, P., \& Kısat, N. Ç. (2016). Yöneticilerin etik liderlik davranışlarının örgütsel adalet ve sinizm üzerine etkileri: Çanakkale il emniyet müdürlügünnde bir araştırma. Yönetim Bilimleri Dergisi, 14(28), 483-509.

Alkan, D.P., \& Arıkboğa, F.Ş. (2017). Etik liderlik ve örgütsel vatandaşlık davranışı ilişkisinde örgütsel özdeşleşmenin aracilık etkisi ve bir uygulama. Yönetim ve Ekonomi, 24(2), 349-369.

Alpkan,L., Dilek, H., \& Bozloğan, R. (2005). Liderlik tarzlarının güven ve adalet algısı yoluyla örgütsel bağlılık, iş tatmini ve örgütsel vatandaşlık davranışı üzerine etkileri. Savunma Bilimleri Dergisi, 4(1), 44-69.

Altıntaş, F.Ç. (2006). Bireysel değerlerin örgütsel adalet ve sonuçları ilişkisinde yönlendirici etkisi: Akademik personel üzerinde bir anali. İşletme Fakültesi Dergisi. 7(2), 19-40.

Ayan, A. (2015). An analysis of he relationship between he perceptions of leadership styles and various job attitudes. Eskişehir Osmangazi Üniversitesi Sosyal Bilimler Dergisi, 16(1), 1-30.

Ayık, A., Yücel, E., \& Savaş, M. (2014). Öğretmenlerin örgütsel adalet algılarının yordayıcısı olarak okul yöneticilerinin etik liderlik davranışları. Abant İzzet Baysal Üniversitesi Ĕ̆gitim Fakültesi Dergisi, 14(2), 233252.

Aykanat, Z., \& Yıldırım, A.(2012). Etik liderlik ve örgütsel adalet ilişkisi: Teorik ve uygulamalı bir araştırma. Firat Üniversitesi Sosyal Bilimler Dergisi, 22(2). 260-274.

Başar, U., Sığrı, U., \& Basım, N. (2017). Etik liderlik algısının örgütsel özdeşleşme üzerindeki etkisinde örgütsel politika algısının düzenleyici rolü. V. Örgütsel Davranış Kongresi, Antalya, 4-5 Kasım 2017.

Brown, M. E., Treviño, L. K., \& Harrison, D. A. (2005). Ethical leadership: a social learning perspective for construct development and testing. Organizational Behaviorand Human Decision Processes, 97(2), 117- 134.

Büyüköztürk, Ş., Kılıç-Çakmak, E., Akgün, E.Ö., Karadeniz, Ş., \& Demirel, F. (2014). Bilimsel araştırma yöntemleri. Ankara: Pegem Akademi Yayıncilık.

Cohen-Charash, Y., \& Spector, P. E. (2001). The role of justice in organizations: A meta-analysis. Organizational Behavior and Human Decision Processes, 86(2), 278-321.

Cheung, M. F., \& Law, M. C. (2008). Relationships of organizational justice and organizational identification: The mediating effects of perceived organizational support in Hong Kong. Asia Pacific Business Review, $14(2), 213-231$.

Cropanzano, R., Byrne, Z. S., Bobocel, D. R., \& Rupp, D. E. (2001). Moral virtues, fairness heuristics, social entities, and other denizens of organizational justice. Journal of Vocational Behavior, 58(2), 164-209.

Cüce, H., Güney, S., \& Tayfur, Ö. (2013). Örgütsel adalet algılarının örgütsel özdeşleşme üzerindeki etkisini belirlemeye yönelik bir araştırma. Hacettepe Üniversitesi İktisadi ve İdari Bilimler Fakültesi Dergisi, 31(1), 130.

Çetinkaya, M., \& Çimenci, S. (2014). Örgütsel adalet algısının örgütsel vatandaşlık davranışı üzerindeki etkisi ve örgütsel özdeşleşmenin aracılık rolü: Yapısal eşitlik modeli çalışması. Yönetim Bilimleri Dergisi, 12(23), 237-278. 
Dalgın, T., \& Taslak, S. (2016). Liderlik uygulamaları örgütsel vatandaşlık davranışları ilişkisinde örgütsel adaletin düzenleyici etkisi: Konaklama işletmeleri üzerine bir araştırma. Gaziantep Üniversitesi Sosyal Bilimler Dergisi, 15(2), 359-393.

Deconinck, J.B., (2011). Theeffects of ethicalclimate on organizational identification, supervisory trust, and turn over amongsales people. Journal of Business Research, 64, 617-624.

Gedikoğlu, T. (2015). Liderlik ve okul yönetimi. Ankara: Anı Yayıncılık.

Hoy, W. K., \& Tarter, C. J. (2004). Organizationa ljustice in schools: No justice without trust. International Journal of Educational Management, 18(4), 250-259.

Irak, D.U. (2004). Örgütsel adalet: Ortaya çıkışı, kuramsal yaklaşımlar ve bugünkü durumu. Türk Psikoloji Yazıları, 7(13), 25-43.

İçerli, L. (2010). Örgütsel adalet: Kuramsal bir yaklaşım. Girişimcilik ve Kalkınma Dergisi, 5(1), 67-92.

İşcan, Ö.F., \& A. Naktiyok; (2004). Çalışanların örgütsel bağdaşımlarının belirleyicileri olarak örgütsel bağlılık ve örgütsel adalet algıları. Ankara Üniversitesi Siyasal Bilgiler Fakültesi Dergisi, 59 (1), Ss.181- 201.

İşcan, Ö.F. (2006). Dönüştürücü/ Etkileşimci liderlik algisı ve örgütsel özdeşleşme ilişkisinde bireysel farklılıkların rolü. Akdeniz İktisadi ve İdari Bilimler Fakültesi Dergisi, 6(11), 160-177.

Kılınç, S. (2017). Yöneticilerin etik liderlik davranışlarının örgütsel özdeşleşme, sapkın davranışlar ve sinizme etkisi. (Yayınlanmamış Yüksek Lisans Tezi). Nevşehir Üniversitesi Sosyal Bilimler Enstitüsü, Nevşehir, Türkiye.

Kolçak, M. (2013). Meslek etiği . Bursa: Ekin Basım Yayın Dağıtım.

Kuğun, O. A., Aktaş.E., \& Güripek E. (2013). Çalışanların örgütsel adalet algılarında yöneticilerin etik liderlik davranışlarının rolü. Balıkesir Üniversitesi Sosyal Bilimler Enstitüsü Dergisi, 16(30), 151-166.

Kumar, S. (2015). Ethical leadership: Linking values tostrategic goals. Journal of Exculisive Management Science, $4(7), 1-9$.

Mael, F., \& Ashforth, B. E. (1992). Alumniand their alma mater: A partial test of there formulated model of organizational identification. Journal of Organizational Behavior, 13, 103-123.

McCabe, N., \& McCarthy, M. (2005). Educating school leaders for social justice. Educational Policy, 19(1), 201222.

Michelic, K.K., Lipicnik, B., \& Tekavcic, M. (2010). Ethical leadership. International Journal Of Managament, 14(5), 31-41.

Moorman, R. H. (1991). Relationship between organizational justice and organizational citizenship behaviors: Do fairness perceptions influence employee citizenship?, Journal of Applied Psychology, 76, 845-855

Nergiz, F. (2015). Öğretmenlerde örgütsel adalet örgütsel özdeşleşme ve işten ayrılma niyetleri arasındaki ilişki: Kahramanmaraş ili Türkoğlu ilçesi örneği. (Yayınlanmamış Yüksek Lisans Tezi). Zirve Üniversitesi Sosyal Bilimler Enstitüsü, Gaziantep, Türkiye.

Olkkonen, M. E., \& Lipponen, J. (2006). Relationships between organizational justice, identification with organization and workunit, and group-relatedoutcomes. Organizational Behavior and Human Decision Processes, 100(2), 202-215.

Öktem, Ş. (2013). The effect of he ethical leadership on perceived organizational justice and organizational identification of theem ployees: The case of tourism businesses. Journal of Tourismand Gastronomy Studies, $1(3), 10-21$. 
Öktem, Ş., Kızıltan, B., \& Öztoprak, M. (2016). Örgütsel güven ile örgüt ikliminin örgütsel özdeşleşme, iş tatmini ve işten ayrılma niyeti üzerine etkileri: Otel işletmelerinde bir uygulama. İşletme Araştırmaları Dergisi, 8(4), 162-186.

Özdemir, M. (2009). Lise öğretmenlerinin etik liderlik ve sosyal adalet algıları arasındaki ilişki. (Yayınlanmış Yüksek Lisans Tezi). Yeditepe Üniversitesi Sosyal Bilimler Enstitüsü, İstanbul, Türkiye.

Özdevecioğlu, M. (2004). Duygusal olaylar teorisi çerçevesinde pozitif ve negatif duygusallı̆̆ın algılanan örgütsel adalet üzerindeki etkilerini belirlemeye yönelik bir araştırma. Ankara Üniversitesi Sosyal Bilimler Dergisi, 59(3), 181-202.

Pillai, R., Teri, A.S., \& Ethlyn, A. W. (1999). Lideship and organizational justice similarities and differances acrosscultures. Journal of International Business Studies, 30 (4), 763-779.

Solmaz, H. (2010). Örgütsel özdeşleşmenin işten ayrlma niyetine etkisinde örgütsel adaletin arabuluculuk rolü. (Yayınlanmamış Yüksek Lisans Tezi). Ufuk Üniversitesi Sosyal Bilimler Enstitüsü, Ankara, Türkiye.

Sonğur, C., Özer, Ö.. \& Şahin, D. (2017). Etik liderliğin örgütsel adalet üzerine etkisi: Bir kamu hastanesinde uygulama. Hacettepe Sağllk İdaresi Dergisi, 20(4), 445-454.

Sökmen, A., Ekmekçioğlu, E.B, \& Çelik, K. (2015). Algılanan örgütsel destek, örgütsel özdeşleşme ve yönetici etik davranışı ilişkisi: araştırma görevlilerine yönelik araştırma. İşletme Araştırma Dergisi, 7(1), 125-144.

Tarkan, G., \& Tepeci, M. (2006). Örgütsel adalet ve yönetimde merkezileşmenin çalışan hırsızlığına etkileri: Mersin üniversitesi turizm işletmeciliği ve otelcilik yüksekokulu öğrenci algılamaları üzerine bir araştırma. Anatolia Turizm Araştırmaları Dergisi, 17(2),137-152.

Taşlıhan, M., Hırlak, B., Çiftçi, G.E., \& Yılmaz, Ö.İ. (2017). Farklılık yönetiminin örgütsel adalet algısı ve örgütsel özdeşleşme üzerine etkisi: İç Anadolu ve Akdeniz bölgesinde yer alan üniversitelerde karşılaştırmalı bir araştırma. Akademik Araştırmalar ve Çalı̧̧ma Dergisi, 9(16), 1-19.

Taşdan, M., \& Yılmaz, K. (2008). Organizational citizenship and organizational justice scales' adaptation to Turkish. TED Ĕ̆itim ve Bilim Dergisi, 33(150), 87-96.

Turan, S. (2015). Okullarda liderlik. S. Turan (Ed.), Eğitim yönetimi, teori, araştırma ve uygulama içinde (ss:375). Ankara: Nobel Yayıncilık.

Tuna, M., Bircan, H., \& Yeşiltaş, M. (2012). Etik liderlik ölçeğinin geçerlik ve güvenirlik çalışması: Antalya örneği. Atatürk Üniversitesi İktisadi ve İdari Bilimler Dergisi, 26(2), 143-155.

Turunç, Ö. (2011). Örgütsel adaletin çalışanların örgütsel özdeşleşme ve işten ayrılma niyetine etkisi: örgütsel özdeşleşmenin aracılık rolü. İ̧s-Güç Endüstri İlişkileri ve İnsan kaynakları Dergisi, 13(1), 143-166.

Türk, M., \& Akbaba, M. (2018). Etik liderlik algısının psikolojik kontrat ihlali ve örgütsel özdeşleme üzerine etkisi: Antalya ilindeki beş yıldızlı konaklama işletmeleri üzerine bir araştırma. Türk İslam Dünyası Sosyal Araştırmalar Dergisi, 5(16), 382-407.

Tziner, A., Felea, M., \& Vasiliu, C. (2015). Relating ethical climate, organizational justice perceptions, and leader-member exchange (LMX) in Romanian organizations. Revista de Psicología del Trabajoy de las Organizaciones, 31(1), 51-57.

Walumbwa FO, Mayer DM, Wang P, Wang H, Workman K., \& Christensen A.L. (2011). Linking ethical leadership to employe eperformance: The roles of leade rmember exchange, self-efficacy, and organizational identification. Organizational Behaviorand Human Decision Processes,115(2),204-213. 
Walumbwa, F. O., Hartnell, C. A., \& Misati, E. (2017). Does ethical leadership enhance group learning behavior? Examining the mediating influence of group ethical conduct, justice climate, and peer justice. Journal of Business Research, 72, 14-23.

Uğurlu, C.T., \& Üstüner, M. (2011). Öğretmenlerin örgütsel bağlllık düzeylerine yöneticilerin örgütsel adalet ve etik liderlik davranışlarının etkisi. Hacettepe Üniversitesi Ĕ̆itim Fakültesi Dergisi,41, 434-448.

Uzun, T. (2018). Okullarda algılanan örgütsel adalet, yönetici desteği ve örgütsel özdeşleşme arasındaki ilişki. Trakya Ĕ̆itim Dergisi, 8(4), 776-789.

Yeşiltaş, M. (2012). Örgütsel özdeşleşmenin oluşmasında belirleyiciler olarak etik liderlik ve etik iklim: Otel işletmelerine yönelik bir uygulama. (Yayınlanmamış Doktora Tezi). Gazi Üniversitesi Sosyal Bilimler Enstitüsü, Ankara, Türkiye. 